\title{
Live Cinema Conference
}

\section{Sarah Atkinson and Helen W. Kennedy}

The Live Cinema Conference held at King's College London on 27 May 2016 was the culmination of research the authors of this report have undertaken to date into the emergent field of live and experiential cinema (Atkinson and Kennedy "Tell No One: Cinema as Game-space", "Where We're Going", "Inside-the-scenes"). It launched four key interventions: the Live Cinema Network, the Live Cinema in the UK Report (Brook), the Participations Journal themed section (Atkinson and Kennedy) and the world's first collaboration between event and live cinema: Hangmen Rehanged (Atkinson and Kennedy). Forty-six speakers and over two hundred participants were either present or connected online for the duration. ${ }^{1}$ Representatives attended from across the film industry, the film exhibition sector, arts and cultural organisations, funding bodies and the academy. ${ }^{2}$ An interdisciplinary steering group of academics and professionals working within the event and live cinema domains developed and curated the programme with the explicit intention to stimulate and advance thinking and practice in this nascent field. The day-long conference was comprised of one keynote (Professor Martin Barker, Aberystwyth University), three panels, two masterclasses, two workshops, an interactive film exhibition-including ROAD (Nick Driftwood, 2015) and fabulous wonder.land (National Theatre, 2015), a networking space and the immersive theatrical screening of Hangmen Rehanged.

This report focuses on the insights and outcomes from the panels and the two masterclasses, while also offering a discussion of the state of our research in this domain. The brief to the panellists was to identify and discuss the critical challenges facing this sector, with selected participation bringing together a diversity of actors in this field. Presenters were asked to discuss a range of topics, including shared and disputed terminology, participation and engagement, marketing and audience development, intellectual property issues, training and education needs, funding and other economic challenges. On analysis of the panel transcripts, we have also identified some further thematics, valuable insights and avenues for future research.

In our research, we have consistently made a clear distinction between live and event cinema (see Table 1) and we sought to bring these two distinct areas of cultural production together in order to identify areas of learning and potential collaboration. The terminology issue stimulated a lot of very productive and occasionally challenging debate throughout the day. No clear consensus emerged around the exact appellations of these domains, but through our analysis of the transcriptions, we have found very clear and consistent lines of separation demonstrating a shared understanding of the differences between the actual experiences themselves. The table below shows how we have captured the vivid distinctions that were articulated by panellists and contributors throughout the day. We have retained the name Event Cinema, given its very strong identity, which has been cultivated and supported by the Event Cinema Association, which is now a mature organisation with an annual conference, a research community and awards recognising the value, technical and aesthetic progress of 
their domain. We have, however, expanded our own term based on the conference discussions to live and experiential, which is the focus of our research and this report (see the glossary by AEA Consulting in "From Live-to-Digital" which makes the same distinction between the Event Cinema and Live Cinema domains).

\begin{tabular}{|c|c|c|}
\hline & Event Cinema & Live \& Experiential Cinema \\
\hline Space \& Place & Cinema auditoria & $\begin{array}{l}\text { Outdoor, urban locations, heritage } \\
\text { sites, theatres and concert halls }\end{array}$ \\
\hline Pricing Structure & $\begin{array}{l}\text { Standard cinema ticket price }+ \\
\text { small premium }\end{array}$ & $\begin{array}{l}\text { Prices vary considerably } \\
\text { depending on level and type of } \\
\text { experience }(£ 15, £ 30, £ 70+) \text { and } \\
\text { these can also be stratified within } \\
\text { the experience (e.g. Secret Cinema } \\
\& \text { Backyard Cinema) }\end{array}$ \\
\hline Rights clearances & $\begin{array}{l}\text { Standard screen license and } \\
\text { partnership agreements }\end{array}$ & $\begin{array}{l}\text { Highly complex range of licenses } \\
\text { and protracted rights negotiations. } \\
\text { Context and differentiated } \\
\text { between artists and exhibitors }\end{array}$ \\
\hline Core technology & $\begin{array}{l}\text { Outside broadcasting \& satellite } \\
\text { transmission }\end{array}$ & $\begin{array}{l}\text { Pop up screens, directional audio, } \\
\text { multiple projections, sound } \\
\text { engineering requirements, live } \\
\text { video mixing techniques }\end{array}$ \\
\hline Content & $\begin{array}{l}\text { Opera, theatre, dance, sport, } \\
\text { concerts, games }\end{array}$ & $\begin{array}{l}\text { Pre-released feature films not } \\
\text { normally new releases }\end{array}$ \\
\hline Temporality/duration & $\begin{array}{l}2-3 \text { hours standard duration of } \\
\text { performance }\end{array}$ & $\begin{array}{l}\text { 3-8 hours with activities \& } \\
\text { interactions pre- } \& \text { post-screening }\end{array}$ \\
\hline Artistic diversity & $\begin{array}{l}\text { Rich high culture offering } \\
\text { spanning the arts }\end{array}$ & $\begin{array}{l}\text { Rich experiential innovations } \\
\text { around what are predominantly } \\
\text { films from the } 1980 \text { s cult } \\
\text { catalogue }\end{array}$ \\
\hline Scaleability & $\begin{array}{l}\text { Global recognition of brand \& } \\
\text { high cultural value, international } \\
\text { market penetration }\end{array}$ & $\begin{array}{l}\text { One-off special events in the UK } \\
\text { or seasonal runs }\end{array}$ \\
\hline Economic Models & $\begin{array}{l}\text { Cultural Partnerships across high } \\
\text { ranking, well-established } \\
\text { organisations }\end{array}$ & $\begin{array}{l}\text { Local, grass roots, community, } \\
\text { entrepreneurs, start ups and SMEs }\end{array}$ \\
\hline Funding Streams & $\begin{array}{l}\text { Public funding, corporate high end } \\
\text { sponsorship }\end{array}$ & $\begin{array}{l}\text { One-off quirky brand sponsorship, } \\
\text { arts funds, ticket revenue }\end{array}$ \\
\hline Impact on Artistic Practices & $\begin{array}{l}\text { Stage performers now on screen: } \\
\text { "lens responsive performance" }\end{array}$ & $\begin{array}{l}\text { Performers respond to the screen: } \\
\text { "screen responsive performance" }\end{array}$ \\
\hline Audience Communications & Mainstream media channels & Social media \& word of mouth \\
\hline
\end{tabular}

Table 1: The key distinctions between "event cinema" and "live and experiential cinema"

\section{Genre Distinctiveness and Market Propositions}

There was a clear sense of a community of practice within which the key players were keen to evolve and express their distinctiveness. This was emphasised during discussions concerning marketing tactics: "We don't just talk about Rooftop Film Club (RFC), we talk about outdoor cinema because we are promoting our industry ... It creates this really big sort of family, and it's great for us as a business" (Cottle). Backyard Cinema described their specific offer as "roaming theatrical cinema": for example, their screening of Romeo \& Juliet (Baz Luhrmann, 1996) was sited in a church and featured a live choir. RFC describe themselves as an "outdoor, rooftop, boutique cinema" (Desumala). Their locations are 
installed with deck chairs, blankets and headphones. Venues feature cocktail bars, street food vendors and gourmet popcorn. Sneaky Experience describes itself as a live experiential organisation - with the strapline: "Don't just watch it, be part of it." Luna Cinema is an openair pop-up cinema. George Wood, Luna Cinema's founder, described the way in which it was a congruent or incongruent juxtaposition of film and site that was frequently key-from staging a screening of Gladiator (Ridley Scott, 2000) in the Tower of London, to screening Jaws (Steven Spielberg, 1975) at an outdoor swimming pool for an audience in dinghies, being circled by a mechanised shark fin. In negotiations with spaces and venues, George Wood described the techniques and technology as very low cost and low impact on the environment. This emphasis or consideration of the place of cinematic consumption is clearly critical; these distinctions are frequently about the external place of the experience and vistas beyond the screen where a particular background adds an additional layer of visual augmentation.

Whilst these organisations were very clear about their identities, others raised challenges in communicating the transdisciplinary and sometimes esoteric nature of these experiences which do not comfortably fit within existing frameworks of understanding. As Jason Wood from HOME commented: "This is a great example of how art forms completely overlap and completely crossover ... it's always difficult to be in the Vanguard, but that's where we find ourselves."

\section{Economic Conditions of Distribution}

Participants argued that the potential for further expansion and development of this industry has been hampered by the dominance of the conventional film distribution model. This makes it very difficult for these innovative exhibitors to secure screening rights for new releases (as discussed in the "Participants, CoCreators, Pawns" panel and the Intellectual Property \& Licensing Masterclass) and raises a question about the potential for sustained growth in this area due to the saturation of the 1980s and 1990s cult oeuvre. "We are being told that if we want to show new releases you have to commit to forty screenings in two weeks. We are an outdoor cinema, we screen at sunset, we can only screen once a day" (Desumala). Jade Desumala, commenting on the Film Policy Review, observed:

They recently found that regular cinemas are running on average at $20 \%$ capacity. We run at $90 \%$. When you look at our venues in the States, we run at $100 \%$. It's a little beyond me as to why a lot of the major distributors can't overlook our shortcomings, ... and not look at what a sociable cinema we are, how much people talk about us, how much press coverage we get.

Julia Benfield underlined this point: "There are systems in place for a reason, but these systems were in place when we didn't exist. I think we now need to re-level the playing field and consider us a part of the cinema industry and no longer ... the black sheep."

\section{Social Media Communication and Marketing}

The interdependency of these emergent forms on the word-of-mouth capabilities of social media was articulated by Emma Keith of National Theatre Live: "We almost say our kind of experiences are built for social media ... For us, it's the extension of our team. I mean 
that." Panellists emphasised the valuable role these channels played in providing immediate audience feedback and a sense of shared experience that then could also feed into and augment marketing opportunities and techniques: "We have a live Twitter feed on the screen and actually we encourage it" (G. Wood). Emma Keith from NT Live stated: "We are probably more likely to say, "Take your phone out, have that collective experience, have that engagement." We certainly encourage phones not to be out during the show but are very encouraging of interval Tweets and preshow Tweets." Both contributors from NT Live talked about how they could respond quickly to comments posted on social media regarding technical issues with the transmissions often to the surprise and delight of the audience members (Murray and Keith).

\section{The Value-Driven and Valued Audience}

Throughout the day, there was a consistent return to the value of the audience, as above in relation to marketing, feedback and the value they bring as co-participants, cocreators and co-marketers of their experiences. This issue of value was also key in the ways in which audiences responded to the price structuring where the "Participants, CoCreators, Pawns" panel discussed value for money and premium-pricing models and price stratification. For this, audience "value" statements related more to the sense of shared experience, the value of being part of a shared community with shared tastes:

Often they would be looking at each other rather than what's on the screen ... They've come dressed up, and I think sometimes we forget these events are emotional, ... They've come to celebrate the Sound of Music [Robert Wise, 1965] they've come to celebrate their relationship with each other ... and the chance to sing at the top of their voice and no one tells them to shut up, no one is embarrassed. (Freedman)

There was also the value of access to new and potentially more diverse audiences for cultural forms such as opera, choir, orchestra, dance, and theatrical performance. In relation to the Royal Albert Hall's "films with live orchestra" series, the following comment was made:

Some of these people have never watched a live orchestra and for them the experience is fantastically overwhelming in a really positive way, and for us it's bringing more people to see live performance in terms of the classical and orchestral side, which has been very important to us, but we've tried to make them as accessible as possible. (Noble)

These experiential and community elements were at the heart of determinations around the value of re-viewing cult films in these dynamic and reimagined spaces.

\section{Intellectual Property, Licensing and Copyright}

Protracted rights negotiations were raised in the "Live Cinema Sound" panel by Ben Freedman and Guy Morley and then became the subject of much discussion within the Intellectual Property (IP) Masterclass, which revealed that there was far more at stake within live and experiential cinema than just IP considerations. For example, where dramatic works 
taken from the film might be recreated - a standard film license would not cover this. Contractual issues, actors and performance rights, trademarking, character licensing and merchandising, celebrity endorsement were also discussed. It was recognised that the dominance of the Hollywood rights model restricted innovation, was highly complex and in need of change:

The number of times that technology has caused people to say that copyright was in crisis goes back centuries and yet we keep on seeing it adapt, because usually what happens is where the technology makes infringement easier, it also provides opportunities for commercialization that didn't previously exist. (Lauriat)

\section{Technology}

Technology was another emergent theme, particularly in relation to the access and quality of screen projection. This was especially the case in the evolution of pop-up and outdoor screenings. Luna Cinema offered a vivid account of how the availability of specific portable, relatively low-cost but high-quality projection equipment allowed for the flourishing of diverse new experiences. Additionally, the "Live Cinema Sound" panel focused on technological issues in relation to music and innovations in sound-based responses to film (see Atkinson and Kennedy "Inside-the-scenes" for the range of these forms). The debate focused on the different sound-mixing demands of a re-scored screening in a variety of venues. Within sing-a-long, live sound track performances and live rescorings, it was noted that these could not currently take place in cinema auditoria. Since live sound engineering techniques were required in order to manipulate the sound levels in response to audience interaction and musical or voice accompaniment (Freedman), theatrical spaces are considered more appropriate to enable this live participative element (Noble). This then produces an additional set of challenges as these spaces are not appropriately acoustically treated for the optimum audibility of film soundtracks in the way that cinema auditoria are (Morley).

\section{Closing Comments}

For live and experiential cinema exhibition to flourish, we propose the following interventions:

- A settled terminology is required if there is to be a satisfactory and adequately critical and aesthetically informed reviewing discourse;

- The risk of saturation of the industry from two directions - the growth of providers and the limitations of access to new content - needs to be tackled;

- Current distribution licensing models need to change and rights regulations need to be more agile;

- Audience reception studies are needed since there was a tendency towards generalisation and assumption rather than evidence-based responses during the discussions;

- A reconfiguration of the traditional physical and virtual cinema auditoria is required if mainstream exhibitors wish to respond to these new cultural forms within their programming strategies. A transformation of the technologies is needed to facilitate 
screen interactions, pre- and post-screening engagements and to accommodate more flexible sound engineering.

\section{Notes}

${ }^{1}$ A USB memory stick containing all of the digital resources, including over seven hours of filmed content, generated by the conference is available to purchase from the King's College London eStore (estore.kcl.ac.uk/).

2 Speakers came from the following organisations: BFI, comScore, Event Cinema Association, National Theatre Live, Luna Cinema, HOME, The Royal Albert Hall, Glyndebourne, Sing-a-long-a Productions Worldwide, Sheffield Doc Fest, Rooftop Film Club, Sneaky Experience, Prince Charles Cinema, Curzon Cinemas, Icon Film Distribution, Harbottle \& Lewis LLP, Picturehouse Entertainment, Vue Entertainment, Backyard Cinema, Edinburgh Film Festival, Creative Skillset, CineLive and Live Cinema UK. In addition to those organisations represented by the speakers, representatives from the Royal Opera House, The Southbank Centre, BBFC, National Media Museum, Disney, The British Museum, Pearl \& Dean Cinema, Arts Council England, and Filmbank Media were also present as delegates.

\section{Works Cited}

AEA Consulting. "From Live-to-Digital: Understanding the Impact of Digital Developments in Theatre on Audiences, Production and Distribution Report, Arts Council England". UK Theatre and Society of London Theatre, 2016.

Atkinson, Sarah. Live Cinema Conference 2016 Digital Resources Pack. King's College London, UK, 2016. estore.kcl.ac.uk/browse/extra_info.asp?compid=1\&modid= 1\&catid=289\&prodid=1690. Accessed 19 Dec. 2016.

Atkinson, Sarah, and Helen W. Kennedy. "Inside-the-scenes: The Rise of Experiential Cinema." Participations: Journal of Audience \& Reception Studies, vol. 13, no. 1, 2016, pp. 139-51.

---. "Secret, Immersive Cinema Is Likely to Change the Future of Film." The Conversation, 1 Dec. 2015, theconversation.com/secret-immersive-cinema-is-likely-to-change-thefuture-of-film-50034. Accessed 30 Sept. 2016.

---. "Tell no one': Cinema as game-space-Audience participation, performance and play." $G|A| M \mid E$ : The Italian Journal of Game Studies, no. 4, 2015, www.gamejournal.it/atkinson_kennedy/. Accessed 30 Sept. 2016.

---. “'Where We're Going, We Don't Need an Effective Online Audience Engagement Strategy': The Case of the Secret Cinema Viral Backlash." Frames Cinema Journal, no. 8, 2015, framescinemajournal.com/article/where-were-going-we-dont-need-aneffective-online-audience-engagement-strategy-the-case-of-the-secret-cinema-viralbacklash/ Accessed 30 Sept. 2016. 
Benfield, Julia. "Participants, Cocreators, Pawns: New Audiences in the Experience Economy.” Live Cinema Conference, 27 May 2016, King's College London, UK.

Brook, Lisa. "Live Cinema in the UK Report 2016.” Arts Council England, 2016.

Cottle, Gerry. "Audience Development Masterclass." Live Cinema Conference, 27 May 2016, King's College London, UK.

Desumala, Jade. "Participants, Cocreators, Pawns: New Audiences in the Experience Economy.” Live Cinema Conference, 27 May 2016, King's College London, UK.

Driftwood, Nick. ROAD. www.driftwoodroad.co.uk. Accessed 30 Sept. 2016.

Freedman, Ben. "Live Cinema Sound: Soundtracks, Singing \& Scoring." Live Cinema Conference, 27 May 2016, King's College London, UK.

Gladiator. Directed by Ridley Scott, DreamWorks Pictures, 2000.

Hangmen Rehanged. Directed by Marie McCarthy, written by Sarah Weatherall, concept \& commissioned by Sarah Atkinson and Helen W. Kennedy, performances by Jack Benjamin, Gavin Duff, Madeleine Hyland and Chris Yarnell, NT Live, Omnibus, Edible Cinema and King's College London, UK, 2016.

Jaws. Directed by Steven Spielberg, Universal Pictures, 1975.

Keith, Emma. "Cultures Separated by a Common Language: What Do We Mean by Live Cinema?" Live Cinema Conference, 27 May 2016, King’s College London, UK.

Lauriat, Barbara. "Intellectual Property \& Licensing Masterclass." Live Cinema Conference, 27 May 2016, King's College London, UK.

Morley, Guy. "Live Cinema Sound: Soundtracks, Singing \& Scoring." Live Cinema Conference, 27 May 2016, King's College London, UK.

Murray, Victoria. "Audience Development Masterclass.” Live Cinema Conference, 27 May 2016, King's College London, UK.

National Theatre. fabulous wonder.land itunes.apple.com/gb/app/fabulous-wonder.land/ id1066348823?mt=8. Accessed 30 Sept. 2016.

Noble, Lucy. "Live Cinema Sound: Soundtracks, Singing \& Scoring." Live Cinema Conference, 27 May 2016, King's College London, UK.

Romeo \& Juliet. Directed by Baz Luhrmann, 20 ${ }^{\text {th }}$ Century Fox, 1996.

Wood, George. "Cultures Separated by a Common Language: What Do We Mean by Live Cinema?” Live Cinema Conference, 27 May 2016, King’s College London, UK. 
Wood, Jason. "Live Cinema Sound: Soundtracks, Singing \& Scoring." Live Cinema Conference, 27 May 2016, King's College London, UK.

\section{Suggested Citation}

Atkinson, Sarah, and Helen W. Kennedy. "Live Cinema Conference." Conference Report. Alphaville: Journal of Film and Screen Media 12 (Winter 2016): 133-40. Web. ISSN: 20094078.

Sarah Atkinson is Senior Lecturer in Digital Cultures at King's College London, UK. Her work is located in digital audience and transmedia studies and is focused upon emergent narrative forms, and new modes of audience access and engagement.

Helen W. Kennedy is Head of the School of Media at the University of Brighton, UK. Her current research interests are feminist interventions into games culture, innovations in experience design and cultural evaluation of live experiences.

Atkinson and Kennedy jointly undertook the first piece of national industry research on the Live Cinema sector with Live Cinema UK, funded by Arts Council England Grants, and are currently collaborating on a Creative Europe funded project-Live Cinema in the EU. 